\title{
Evaluation of the therapeutic efficacy of clindamycin in patients hospitalised with erysipelas
}

\author{
Ocena skuteczności terapeutycznej klindamycyny u hospitalizowanych chorych \\ na różę
}

\author{
José Maria Pereira de Godoyํㅗㄹ André Luís Cozetto de Oliveira², Maria de Fátima Guerreiro Godoy² \\ ${ }^{1}$ Department of the Medicine, School in São José do Rio Preto (FAMERP) and CNPq (National Council for Research and Development), \\ Brazil \\ ${ }^{2}$ Medicine School, São Jose do Rio Preto (FAMERP), Brazil
}

Key words: erysipelas, antibiotic therapy, clindamycin, microbial resistance.

Słowa kluczowe: róża, antybiotykoterapia, klindamycyna, oporność bakterii.

\begin{abstract}
Introduction: Erysipelas is an acute skin infection of a streptococcal-related aetiology. Penicillin is the first-line antibiotic in the treatment of erysipelas; however, a number of other antibiotics are used.

Aim of the research: To evaluate the clinical response of erysipelas to clindamycin in hospitalised patients.

Material and methods: A retrospective cohort study was performed of all patients hospitalised with erysipelas and treated with the antibiotic clindamycin in Hospital de Base, São José do Rio Preto between 2000 and 2008.

Results: The efficacy of this medication was evaluated. Failure of clinical treatment was detected in $4 \%$ of the 50 patients treated with clindamycin, but no failure was seen in 51 patients who were treated with clindamycin combined with other antibiotics. Conclusions: Clindamycin is clinically efficacious (96\%) to treat patients hospitalised for erysipelas. Clindamycin is a good therapeutic option.
\end{abstract}

\section{Streszczenie}

Wprowadzenie: Róża jest ostrym stanem zapalnym skóry wywołanym przez paciorkowce. Antybiotykiem pierwszego rzutu w leczeniu róży jest penicylina, jednak stosuje się również wiele innych antybiotyków.

Cel pracy: Ocena odpowiedzi klinicznej róży na klindamycynę u chorych hospitalizowanych.

Materiał i metody: Przeprowadzono retrospektywne badanie kohortowe wszystkich pacjentów hospitalizowanych z powodu róży i leczonych klindamycyną w Hospital de Base, Sao Jose do Rio Preto w latach 2000-2008.

Wyniki: Dokonano oceny skuteczności tego leczenia. Brak odpowiedzi klinicznej odnotowano u 4\% spośród 50 pacjentów leczonych klindamycyną, przy czym niepowodzenia nie odnotowano u 51 pacjentów, u których zastosowano terapię klindamycyną w połączeniu z innymi antybiotykami.

Wnioski: Klindamycyna wykazuje skuteczność kliniczną (96\%) w leczeniu w szpitalu chorych na różę. Klindamycyna jest dobrym wyborem terapeutycznym.

\section{Introduction}

Erysipelas is an acute skin infection that involves the dermis and hypodermis, it affects the lymph ducts, thus causing a more extensive subcutaneous infection than cellulitis [1]. It is, in most cases, caused by group A $\beta$-haemolytic streptococcus (Streptococcus pyogenes), but other agents such as other $\beta$-haemolytic streptococci have also been reported [2, 3]. It is considered a universal infection, with an estimated incidence of 200 cases per 100,000 inhabitants/year [4].

The treatment of cellulitis and erysipelas is based on, in general, empirically chosen antibiotic thera- py, with penicillin $G$ therapy being recommended by many studies [3-5]. The use of other antibiotics, such as other types of penicillin (crystalline penicillin, amoxicillin, oxacillin), clindamycin, macrolides (erythromycin), and cephalosporins (cephalexin, cefazolin), has also been reported [6, 7].

\section{Aim of the research}

The aim of this study is to evaluate the clinical response of erysipelas to clindamycin in hospitalised patients. 


\section{Material and methods}

A retrospective cohort study was performed of all patients hospitalised with erysipelas and treated with the antibiotic clindamycin in Hospital de Base, São José do Rio Preto between 2000 and 2008.

The diagnosis of erysipelas was based on clinical signs and symptoms such as a temperature greater than $37.8^{\circ} \mathrm{C}$, chills, an elevated temperature of the involved limb, and local hyperaemia.

The inclusion criteria were the use of clindamycin as the first-line option in the treatment of erysipelas and patients submitted to antibiotic therapy for less than 3 days. Cases with incomplete data or hospital records that were incorrectly filled out were excluded from the study. Treatment was considered successful when the patient was healed with the medication.

The Fischer exact test was employed for statistical analysis with an $\alpha$ error of $5 \%$ being considered acceptable. The study was approved by the Research Ethics Committee of the institution (Protocol No. 080/2008), and informed consent from patients was not necessary because this was a retrospective study.

\section{Results}

This study involved 101 hospitalised patients, 50 of whom took clindamycin for the treatment of erysipelas and 51 took clindamycin combined with another antibiotics. The mean age of the patients who took clindamycin in isolation was $56.7 \pm 19.6$ years and for those who took two antibiotics it was $60.5 \pm 18.2$ years; there was no significant difference between the mean ages of the two groups.

Two (4\%) patients out of the 50 who were treated with clindamycin alone, and none of the two antibiotic groups, failed treatment. Table 1 lists the combinations of antibiotics used to treat erysipelas.

Twenty patients were re-admitted; 3 within 15 days of discharge and 17 after 1 month (mean: 14.25 months).

\section{Discussion}

This retrospective cohort study of the therapeutic response of erysipelas to clindamycin detected

Table 1. Treatment of erysipelas with clindamycin and associated antibiotics

\begin{tabular}{|lc|}
\hline Antibiotic & No. of patients \\
Clindamycin & 50 \\
Clindamycin and amikacin & 24 \\
Clindamycin and amoxicillin & 1 \\
Clindamycin and ceftriaxone & 7 \\
Clindamycin and ciprofloxacin & 16 \\
Clindamycin and penicillin & 3 \\
\hline
\end{tabular}

treatment failure in $4 \%$ of the patients treated with this medication alone. When other antibiotics were associated with clindamycin, the treatment was successful for all patients. As the sample size was small in this study, no firm conclusion can be reached as to whether there are significant differences between the use of clindamycin in isolation and combined with other antibiotics. All patients were followed-up in the outpatient clinic after hospital discharge.

Another aspect that draws attention in this study is that around $20 \%$ of patients were re-admitted for erysipelas during the follow-up period (mean: 14.25 months), showing that relapse must be a major concern; these figures do not include patients treated on an outpatient basis after hospital discharge. Relapse is the most common complication (25\%) and so proper treatment of risk factors is essential [6].

Another publication from the same service as this study reported that $77 \%$ of patients with two or more episodes of erysipelas suffered from clinical or subclinical lymphoedema [8]. Studies warn about the high frequency of associations with other comorbidities. These include hypertension, diabetes mellitus, chronic venous insufficiency, and other cardiovascular diseases including angina, peripheral arterial disease, myocardial infarction and stroke, obesity, chronic renal failure, cancer, cirrhosis, chronic lymphoedema, and leg ulcers [1,9]. The association with pneumonia, sepsis, and cancer were significantly associated with mortality [10].

This study has a limitation because it is retrospective, but it addresses the therapeutic success of the drug. Accurate data on the causes of treatment failure and the criteria of antibiotic combinations may provide new information for the therapeutic approach. Another aspect is the lack of culture and antibiogram that would provide further data.

\section{Conclusions}

Clindamycin proved efficacious in more than $96 \%$ of patients hospitalised for the treatment of erysipelas and is therefore a good therapeutic option.

\section{Conflict of interest}

The authors declare no conflict of interest.

\section{References}

1. Pereira de Godoy JM, Galacini Massari P, Yoshino Rosinha M, Marinelli Brandao R, Foroni Casas AL. Epidemiological data and comorbidities of 428 patients hospitalized with erysipelas. Angiology 2010; 61: 492-494.

2. Erysipelas GE. Clinicopathological classification and terminology. Ann Dermatol Venereol 2001; 128: 307-311.

3. Bonnetblanc JM, Bedane C. Erysipelas: recognition and management. Am J Clin Dermatol 2003; 4: 157-163.

4. McNamara DR, Tleyjeh IM, Berbari EF, Lahr BD, Martinez JW, Mirzoyev SA, Baddour LM. Incidence of lower-extre- 
mity cellulitis: a population-based study in Olmsted county, Minnesota. Mayo Clin Proc 2007; 82: 817-821.

5. Bishara J, Golan-Cohen A, Robenshtok E. Uso de antibióticos em pacientes com erisipela: um estudo retrospectivo. Isr Med Assoc J 2001; 3: 722-724.

6. Stevens DL, Bisno AL, Chambers HF, Dellinger EP, Goldstein EJ, Gorbach SL, Hirschmann JV, Kaplan SL, Montoya JG, Wade JC. Practice guidelines for the diagnosis and management of skin and soft-tissue infections. Clin Infect Dis 2005; 41: 1373.

7. Kilburn SA, Featherstone P, Higgins B, Brindle R. Interventions for cellulitis and erysipelas. Cochrane Database Syst Rev 2010; 6: CD004299.

8. de Godoy JM, de Godoy MF, Valente A, Camacho EL, Paiva EV. Lymphoscintigraphic evaluation in patients after erysipelas. Lymphology 2000; 33: 177-180.

9. Pereira De Godoy JM, Augusto Dos Santos R, Vilela Filho RA, Guerreiro Godoy Mde F. Erysipelas and ulcer of the legs in patients with lipolymphedema. Eur J Dermatol 2011; 21: 101-102.

10. Rosinha MY, Massa PG, Brandão RM, Casas ALF. Prevalence of mortality in patients hospitalized due to erysipelas and related comorbidities. J Phlebol Lymphol 2010; 3: $8-10$

\section{Address for correspondence:}

José Maria Pereira de Godoy MD, PhD

Department of the Medicine

School in São José do Rio Preto (FAMERP)

and $\mathrm{CNPq}$ (National Council for Research and Development)

Rua Floriano Peixoto 2950

São José do Rio Preto, SP Brazil

CEP: 15010-020

E-mail: godoyjmp@riopreto.com.br 